ENVIRONMENTAL EXPOSURE

\title{
Association between air pollution exposure and exhaled nitric oxide in an elderly population
}

\author{
G Adamkiewicz, S Ebelt, M Syring, J Slater, F E Speizer, J Schwartz, H Suh, D R Gold
}

Thorax 2004;59:204-209. doi: 10.1136/thorax.2003.006445

See end of article for authors' affiliations

Correspondence to:

Dr G Adamkiewicz

Exposure, Epidemiology

and Risk Program,

Harvard School of Public

Health, 401 Park Drive,

Boston, MA 02115, USA;

gadamkie@

hsph.harvard.edu

Received 7 March 2003

Accepted

2 November 2003
Background: Animal models suggest that the cardiovascular effects of air pollution result in part from inflammation caused by proinflammatory mediators originating in the lung. In a human study of the cardiovascular effects of air pollution, we aimed to evaluate the potential association between air pollution levels and the fraction of exhaled nitric oxide ( $\mathrm{F}_{\mathrm{NO}}$ ), a non-invasive measure of airway inflammation. Methods: Breath samples were collected weekly between September and December 2000 in a community based group of elderly subjects (median age 70.7 years) in Steubenville, Ohio. The samples were analysed for NO. Air pollution levels were measured concurrently at a central site monitor.

Results: An increase in the 24 hour average $\mathrm{PM}_{2.5}$ concentration of $17.7 \mu \mathrm{g} / \mathrm{m}^{3}$ was associated with an increase in $\mathrm{FE}_{\mathrm{NO}}$ of $1.45 \mathrm{ppb}(95 \% \mathrm{Cl} 0.33$ to 2.57$)$ in models adjusted for subject, week of study, day of the week, hour of the day, ambient barometric pressure, temperature, and relative humidity. This represents a change of approximately $15 \%$ compared with the mean FENO in the cohort (9.9 ppb). A significant association was also observed for a 24 hour moving average of ambient NO $10.83 \mathrm{ppb}$ increase, $95 \% \mathrm{Cl} 0.26$ to 1.40). In two-pollutant models, the magnitude and precision of the $\mathrm{PM}_{2.5}$ effect was not reduced and the ambient NO effect was no longer significant. The associations between FENO and $\mathrm{PM}_{2.5}$ were significantly higher in subjects with a doctor's diagnosis of COPD ( $\mathrm{p}$ value for interaction $=0.03$ ).

Conclusions: Ambient pollution may lead to airway inflammation as measured by $\mathrm{FE}_{\mathrm{NO}}$. These subclinical inflammatory changes may be an important step in the pathogenesis of the cardiopulmonary effects induced by exposure to air pollution.
$\mathrm{N}$ umerous studies have reported an association between ambient pollution and excess morbidity and mortality from cardiovascular and respiratory diseases. ${ }^{12}$ The underlying mechanisms responsible for these associations are not well understood. However, accumulating data suggest that ambient particle pollution may lead to pulmonary inflammation, ${ }^{34}$ resulting in either systemic autonomic effects $^{5}{ }^{6}$ and/or the dissemination of systemic proinflammatory products (such as cytokines) that may influence vascular tone and cardiovascular function. ${ }^{7}$ Inflammatory processes play a key role in many lung diseases including asthma and chronic obstructive pulmonary disease (COPD). ${ }^{89}$ In recent years it has also been proposed that the pathophysiology of cardiovascular disease may be related to systemic inflammatory processes. ${ }^{10}$

Nitric oxide (NO) is a short lived intercellular messenger that has been shown to be important in a wide range of biological functions including neurotransmission, ${ }^{11}$ host defence, ${ }^{12}$ immune function, ${ }^{13}$ and inflammation; ${ }^{14}$ many of these processes are relevant to pulmonary and cardiovascular pathophysiology. In the lung, macrophages, neutrophils, epithelial cells, endothelial cells, and non-adrenergic noncholinergic neurones are capable of producing NO. ${ }^{15}$ The production of endogenous NO is controlled by the various isoforms of nitric oxide synthase (NOS), broadly classified as constitutive and inducible NOS (iNOS). The activation of the inducible form (iNOS) by proinflammatory cytokines is believed to be primarily responsible for the increased production of NO observed in asthma. ${ }^{14}$

Previous studies have shown that the measurement of NO concentrations in expired air may represent a non-invasive measure of airway inflammation. Specifically, exhaled NO has been shown to be an associated marker in chronic cough, ${ }^{16} \mathrm{COPD}_{,}{ }^{17}$ and asthma. ${ }^{18}$ Additional pathways have been suggested for the observed increases in exhaled NO. For example, recent evidence has shown that acidification of the airways, which is known to have important toxicological consequences, ${ }^{19}$ may enhance the production of $\mathrm{NO}$ in the lung. ${ }^{20}$

Few studies have examined the effect of air pollution exposure on subclinical inflammatory markers such as NO. Van Amsterdam et $a^{21}$ compared morning ambient air pollution levels with levels of exhaled NO on 14 consecutive work days in 16 non-smoking adults. The strongest associations with exhaled NO were found for ambient $\mathrm{NO}$ and carbon monoxide (CO). In a longitudinal study of elementary schoolchildren aged 8-13 years Steerenberg et al $^{22}$ found that exposure to black smoke, $\mathrm{NO}$, nitrogen dioxide $\left(\mathrm{NO}_{2}\right)$, and particulate matter smaller than $10 \mu \mathrm{m}\left(\mathrm{PM}_{10}\right)$ were associated with increased levels of exhaled NO. These pollutants were also associated with a reduction in peak expiratory flow and increases in inflammatory markers in nasal lavage samples. No previous studies have examined the association between air pollution exposure and exhaled $\mathrm{NO}$ in the elderly, who may be more vulnerable to the effects of pollution. We have examined the association between short term changes in exhaled NO as a function of ambient air

Abbreviations: COPD, chronic obstructive pulmonary disease; ECG, electrocardiogram; $\mathrm{EEN}_{\mathrm{NO}}$, fraction of exhaled nitric oxide; GLM, generalised linear model; IL-6, interleukin 6; IQR, interquartile range; $\mathrm{NO}$, nitric oxide; $\mathrm{NO}_{2}$, nitrogen dioxide; NOS, nitric oxide synthase; $\mathrm{NOx}$, oxides of nitrogen; $\mathrm{O}_{3}$, ozone; $\mathrm{PM}_{2.5}$, particulate matter less than $2.5 \mu \mathrm{m}$ in aerodynamic diameter; $\mathrm{PM}_{10}$, particulate matter less than $10 \mu \mathrm{m}$ in aerodynamic diameter; $\mathrm{SO}_{2}$, sulphur dioxide; TNF- $\alpha$, tumour necrosis factor $\alpha$. 
pollution exposure in a community based elderly population followed repeatedly over a 3 month period.

\section{METHODS \\ Study cohort and protocol}

In August 2000, 29 non-smoking adult volunteers were recruited in Steubenville, Ohio. This study was part of a study of cardiovascular end points, so exclusion criteria were selected based on the results of a resting 12-lead ECG performed at screening and certain cardiovascular conditions that would limit the measurement of heart rate variability. Exclusion criteria included unstable angina, atrial flutter, atrial fibrillation or paced rhythm. Based on our cardiovascular protocol, the ability to walk on level ground was an inclusion criterion. During screening, patients were asked if they had ever smoked or if they had ever received a doctor's diagnosis of asthma or COPD. Exhaled NO monitoring was conducted over 12 weeks from late September through December 2000 by study personnel who were blinded to all air pollution monitoring. The study rooms were located in two apartment buildings where most of the subjects lived. Each participant was assigned randomly to a day (MondayFriday) and time (09.00-17.00 hours) for his or her weekly appointment.

\section{Collection and analysis of breath samples}

The sampling procedures were established in accordance with guidelines published by the American Thoracic Society for the collection of breath samples for offline NO analysis. ${ }^{23}$ The breath sample collection device was assembled from standard mouthpieces and fittings used for spirometric testing using one-way valves to separate inspiratory and expiratory flows. Because of the potential for contamination of breath samples with ambient NO, inspiratory air was scrubbed using an NO filter consisting of Purafil followed by activated carbon. In addition, at each session a 3 litre spirometric calibration syringe was used to fill a mylar balloon with a sample of air from the study room, which was analysed for NO.

Inspiratory filtered room air was breathed for 30 seconds of normal tidal breathing. The subject was then asked to inspire to total lung capacity; a mylar balloon was immediately connected to the expiratory port following inspiration which was clamped shut following expiration. The expiratory flow was controlled by having the subject maintain a pressure of $12.5 \mathrm{~cm} \mathrm{H}_{2} \mathrm{O}$ on a pressure gauge attached to the collection device and visible to the subject. Exhalation against this pressure accomplishes two goals. First, it insures elevation of the soft palate, thus isolating the nasopharynx from the desired lower airway sample. In addition, it normalises each subject's expiratory flow rates which can influence exhaled NO concentrations. ${ }^{23}$ This pressure approximately corresponds to a flow rate of $0.350 \mathrm{l} / \mathrm{s}$.

Levels of NO in breath samples collected during a single session can fluctuate as a result of variations in the individual breathing manoeuvres-for example, brief breath hold or interruption of tight mouth seal. ${ }^{23}$ Three sequential breath samples from each subject were therefore collected at each session and the median of these samples was used as a stable measure of exhaled NO. Each mylar balloon was sealed immediately after exhalation and analysed later that day. Breath and room air samples were analysed for NO using a thermoenvironmental model 42 chemiluminescence oxides of nitrogen (NOx) analyser.

\section{Exposure monitoring}

Ambient air sampling was conducted at a central site in Steubenville and included continuous measurements for airborne particles with an aerodynamic diameter $\leqslant 2.5 \mu \mathrm{m}$ $\left(\mathrm{PM}_{2.5}\right)$, gaseous pollutants, and meteorological parameters.
Air pollutants were measured continuously and reported as hourly averaged concentrations (monitoring equipment: $\mathrm{PM}_{2.5}$ : R\&P model 1400A tapered element oscillating microbalance (TEOM); $\mathrm{SO}_{2}$ : API model $100 \mathrm{UV}$ fluorescence monitor; $\mathrm{O}_{3}$ : API model 400 UV monitor; NOx: API model 200A chemiluminescent NOx analyser). Hourly lags and 24 hour moving averages of these pollutants were determined from these measurements. Meteorological data (temperature, barometric pressure, and relative humidity) were collected using a Met-1 10 metre station.

\section{Statistical analysis}

Fixed effect models were used to determine associations between exhaled NO and the main variables of interest-air pollutant exposures on various time scales. These models fit subject specific intercepts to capture the effect of all time invariant attributes, both measured and unmeasured. Time variant parameters were used to model the effect of meteorology, pollutant exposure, and NO levels in the study room. Since exhaled NO levels may be affected by the timing of breath sample collections irrespective of exposure, we adjusted for the time of day, day of the week, and the week of study. For example, exhaled NO, like many biomarkers, has been shown to have a circadian rhythm. ${ }^{24}$

Univariate associations between subject attributes (for example, COPD diagnosis) and exhaled NO were analysed using repeated measure analysis of variance (ANOVA) tests on the log transformed $\mathrm{FE}_{\mathrm{NO}}$ measurements. These data were not transformed in the models of pollutant effects since the distribution of each subject's weekly deviance from his or her study mean was approximately normal.

Models were created to examine the relative roles of various exposure windows on exhaled NO concentrations, as well as the relative roles of individual pollutants, which were highly correlated. Separate models for individual hourly lag models were created, as well as moving average models to reflect cumulative exposures. All modeling was performed using the GLM procedure in SAS (SAS Institute, 1997). To test whether there was heterogeneity in response to $\mathrm{PM}_{2.5}$, we also fit mixed models allowing a random slope-that is, each subject's slope for $\mathrm{PM}_{2.5}$ was allowed to vary randomly about the population mean slope. We then tested whether the variability in slopes was significant. In separate mixed models we investigated the potential interactions between reported respiratory disease and the relationship between $\mathrm{PM}_{2.5}$ and $\mathrm{FE}_{\mathrm{NO}}$.

\section{RESULTS}

A total of 294 breath samples were collected. Of the 29 subjects in the study, 22 completed at least 10 of their 12 scheduled sessions. Approximately 30 individual sampling sessions were missed due to illness, recruitment delays, holidays, and other scheduling conflicts. An additional 24 samples were not usable because of insufficient breath volume or problems with our analytical equipment. Subject characteristics and their relationship with $\mathrm{FE}_{\mathrm{NO}}$ levels are shown in table 1 . The study population was predominantly female with a median age of 70.7 years. While the median exhaled $\mathrm{FE}_{\mathrm{NO}}$ levels were higher for those with asthma and COPD, we did not observe statistically significant differences in $\mathrm{FE}_{\mathrm{NO}}$ by disease status. Four subjects reported having received, at some time, both a doctor's diagnosis of asthma and of COPD. Pollution concentrations used in this analysis are shown in table 2 .

Individual hourly lag models showed consistent associations between $\mathrm{PM}_{2.5}$ and $\mathrm{FE}_{\mathrm{NO}}$ for exposures during the previous 24 hours (fig 1). Based on the trend in these results, 24 hour moving averages were created to reflect the most relevant window of exposure. Table 3 shows the associations 


\begin{tabular}{|c|c|c|c|c|c|}
\hline \multirow[b]{2}{*}{ Characteristic } & \multirow{2}{*}{$\begin{array}{l}\text { No }(\%) \text { of } \\
\text { subjects }\end{array}$} & \multirow{2}{*}{$\begin{array}{l}\text { No of } \\
\text { samples }\end{array}$} & \multicolumn{3}{|c|}{$\mathrm{FE}_{\mathrm{NO}}$ measurements } \\
\hline & & & Mean (ppb) & Median (ppb) & Range (ppb) \\
\hline All subjects & 29 & 294 & 9.9 & 8.7 & $0.3-62.8$ \\
\hline \multicolumn{6}{|l|}{ Sex } \\
\hline Male & $2(6.9)$ & 22 & 9.6 & 7.9 & $1.5-23.7$ \\
\hline Female & $27(93.1)$ & 272 & 9.9 & 8.7 & $0.3-62.8$ \\
\hline \multicolumn{6}{|c|}{ Age (range $53.5-90.6$ years) } \\
\hline$\leqslant 70$ years & $14(48.3)$ & 136 & 8.3 & 7.4 & $0.3-25.4$ \\
\hline$>70$ years & $15(51.7)$ & 158 & 11.2 & 9.5 & $3.8-62.8$ \\
\hline \multicolumn{6}{|l|}{ Race/ethnicity } \\
\hline Black & $9(31.0)$ & 84 & 8.8 & 8.4 & $0.3-21.5$ \\
\hline White & $20(69.0)$ & 210 & 10.3 & 8.7 & $1.5-62.8$ \\
\hline \multicolumn{6}{|l|}{ COPD ever } \\
\hline Yes & $7(24.1)$ & 76 & 11.9 & 10.0 & $1.9-62.8$ \\
\hline No & $22(75.9)$ & 218 & 9.2 & 8.2 & $0.3-32.4$ \\
\hline \multicolumn{6}{|l|}{ Asthma ever } \\
\hline Yes & $8(27.6)$ & 74 & 12.1 & 10.1 & $1.9-62.8$ \\
\hline No & $21(72.4)$ & 220 & 9.1 & 8.1 & $0.3-32.4$ \\
\hline \multicolumn{6}{|c|}{ Cigarette smoking } \\
\hline Never & $16(55.2)$ & 156 & 9.8 & 8.9 & $0.3-32.4$ \\
\hline Former & $13(44.8)$ & 138 & 9.9 & 8.0 & $1.5-62.8$ \\
\hline Current & 0 & - & - & - & - \\
\hline \multicolumn{6}{|c|}{ Myocardial infarction ever } \\
\hline Yes & $5(17.2)$ & 57 & 10.3 & 9.2 & 4.2-24.9 \\
\hline No & $24(82.8)$ & 237 & 9.7 & 8.4 & $0.3-62.8$ \\
\hline
\end{tabular}

between air pollution levels (current hour and 24 hour moving averages) and changes in exhaled NO concentrations. An interquartile range (IQR) increase in the mean $\mathrm{PM}_{2.5}$ concentrations during the previous 24 hours of $17.7 \mu \mathrm{g} / \mathrm{m}^{3}$ was associated with an increase in $\mathrm{FE}_{\mathrm{NO}}$ of $1.45 \mathrm{ppb}(95 \%$ confidence interval (CI) 0.33 to 2.57). This represents a change of approximately $15 \%$ compared with the mean $\mathrm{FE}_{\mathrm{NO}}$ in the cohort (9.9 ppb). Similarly, an IQR increase in the mean ambient NO concentration during the previous 24 hours of $11.9 \mathrm{ppb}$ was associated with an increase in $\mathrm{FE}_{\mathrm{NO}}$ of $0.83 \mathrm{ppb}$ (95\% CI 0.26 to 1.40). Current hour concentrations were also significant for these pollutants. No significant associations were observed for $\mathrm{SO}_{2}, \mathrm{NO}_{2}$, or $\mathrm{O}_{3}$. When the 24 hour moving average of $\mathrm{PM}_{2.5}$ was included in a model with current $\mathrm{PM}_{2.5}$, the 24 hour exposure effect was unchanged while the current hour effect was reduced by $34 \%$ (model not shown). In multi-pollutant models the association with $\mathrm{PM}_{2.5}$ appeared to be the most robust (table 4). The association with ambient NO was reduced $(\mathrm{p}<0.1)$ in models with $\mathrm{PM}_{2.5}$, while the $\mathrm{PM}_{2.5}$ association increased and remained significant (model 1). The 24 hour $\mathrm{NO}$ and $\mathrm{PM}_{2.5}$ effects remained significant in models that included room NO concentrations (models 2 and 3). The $\mathrm{PM}_{2.5}$ effect remained significant in a model that controlled for both ambient NO and NO concentrations in the study room (model 4).

When we repeated our model using a random slope for each subject there was significant heterogeneity among subjects in response to $\mathrm{PM}_{2.5}(\mathrm{p}=0.0026)$. The 24 hour $\mathrm{PM}_{2.5}$ effect estimates for the seven subjects reporting a COPD diagnosis were significantly higher than for normal subjects (3.9 $v 0.8 \mathrm{ppb}$ for an interquartile change in $\mathrm{PM}_{2.5}$, $\mathrm{p}$ value for interaction $=0.03$ ). Subjects reporting both asthma and COPD were similar in their $\mathrm{PM}_{2.5}$ response to

Table 2 Ambient pollution and meteorological variables during breath sampling

\begin{tabular}{|c|c|c|c|c|c|c|}
\hline \multirow[b]{2}{*}{ Pollutant } & \multirow[b]{2}{*}{ No } & \multirow[b]{2}{*}{ Mean } & \multirow[b]{2}{*}{ Max } & \multicolumn{2}{|c|}{ Percentile } & \multirow[b]{2}{*}{ Interquartile range } \\
\hline & & & & 25th & 75th & \\
\hline \multicolumn{7}{|l|}{$\mathrm{PM}_{2.5}\left(\mu \mathrm{g} / \mathrm{m}^{3}\right)$} \\
\hline 1 hour mean & 261 & 19.5 & 105.8 & 7.6 & 25.5 & 17.9 \\
\hline 24 hour mean & 291 & 19.7 & 57.8 & 9.7 & 27.4 & 17.7 \\
\hline \multicolumn{7}{|l|}{ Ambient NO (ppb) } \\
\hline 1 hour mean & 216 & 15.0 & 215.3 & 1.6 & 16.1 & 14.5 \\
\hline 24 hour mean & 244 & 11.2 & 70.7 & 2.3 & 14.2 & 11.9 \\
\hline \multicolumn{7}{|l|}{ Indoor NO (ppb) } \\
\hline Study room* & 293 & 24.4 & 137.2 & 2.9 & 32.6 & 29.6 \\
\hline \multicolumn{7}{|l|}{$\mathrm{NO}_{2}$ (ppb) } \\
\hline 1 hour mean & 140 & 9.2 & 32.9 & 4.7 & 12.8 & 8.1 \\
\hline 24 hour mean & 179 & 10.9 & 23.8 & 7.3 & 14.6 & 7.3 \\
\hline \multicolumn{7}{|l|}{$\mathrm{O}_{3}(\mathrm{ppb})$} \\
\hline 1 hour mean & 236 & 19.8 & 61.6 & 8.6 & 27.5 & 18.9 \\
\hline 24 hour mean & 265 & 15.3 & 32.2 & 9.7 & 20.2 & 10.6 \\
\hline \multicolumn{7}{|l|}{$\mathrm{SO}_{2}(\mathrm{ppb})$} \\
\hline 1 hour mean & 252 & 14.8 & 233.9 & 3.7 & 15.2 & 11.5 \\
\hline 24 hour mean & 287 & 12.5 & 50.9 & 5.4 & 16.9 & 11.5 \\
\hline \multicolumn{7}{|l|}{ Temperature $\left({ }^{\circ} \mathrm{C}\right)$} \\
\hline 24 hour mean & 299 & 7.0 & 19.4 & 1.4 & 13.1 & 11.6 \\
\hline
\end{tabular}




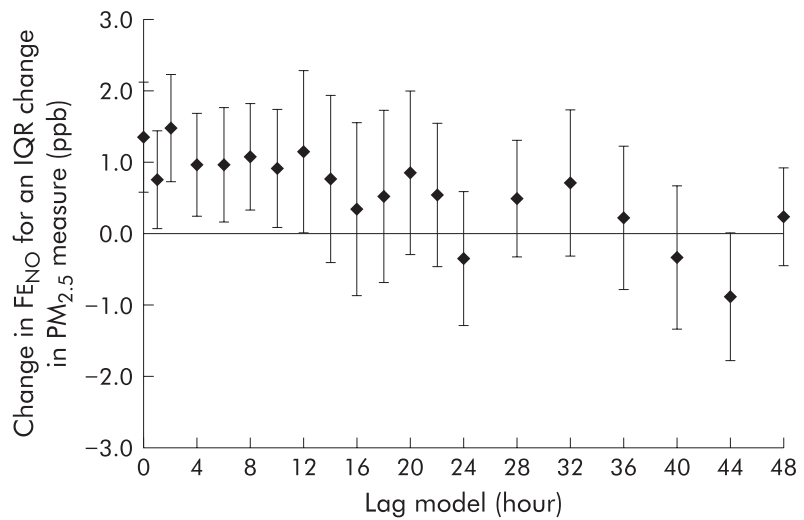

Figure 1 Association of $\mathrm{FE}_{\mathrm{NO}}$ with $\mathrm{PM}_{2.5}$ at different lags between exposure and effect. Change in $\mathrm{FE}_{\mathrm{NO}}(\mathrm{ppb})$ for an interquartile change in $\mathrm{PM}_{2.5}$ measure for individual hourly lag models. Error bars indicate 95\% confidence interval. Each model includes lagged $\mathrm{PM}_{2.5}$ measure, subject ID, week of study, day of week, hour of day, and 24 hour mean temperature, pressure, and relative humidity.

those reporting only COPD. Subjects who reported only asthma did not exhibit $\mathrm{PM}_{2.5}$ responses that were different from normal subjects. While the interaction term for COPD was significant, significant heterogeneity in response remained $(p=0.0047)$ after controlling for that effect modifier. This indicates that other factors are also responsible for the observed heterogeneity in response to pollution.

\section{DISCUSSION}

This study has shown that exposure to ambient air pollution in an elderly population is associated with an increase in exhaled NO, a marker of pulmonary inflammation. Specifically, ambient $\mathrm{NO}$ and $\mathrm{PM}_{2.5}$ were associated with $\mathrm{FE}_{\mathrm{NO}}$ across various exposure windows during the previous day's exposure. Two-pollutant models suggest that other pollutants did not confound the $\mathrm{PM}_{2.5}$ effect.

Previous studies have shown associations between ambient pollution and exhaled NO. A recent panel study also reported an association between exhaled $\mathrm{NO}$ and ambient $\mathrm{NO}, \mathrm{NO}_{2}$, black smoke, and particulate matter $\mathrm{PM}_{10}$ in children living in urban areas. ${ }^{22}$ Our study is the first to examine the association between pollution exposure in another potentially sensitive subpopulation, the elderly. We also were able specifically to assess the fraction of particulate matter that has been most closely associated with health effects in previous studies-namely, $\mathrm{PM}_{2.5}$. While ambient air typically contains many pollutants whose concentrations are highly correlated due to common sources (for example, traffic and industry) and local meteorological control over atmospheric

Table 3 Exposure effect estimates: single pollutant models

\begin{tabular}{|c|c|c|c|}
\hline \multirow[b]{2}{*}{ Pollutant } & & \multicolumn{2}{|c|}{$\begin{array}{l}\text { Change in } F_{E_{N O}}(\mathrm{ppb}) \text { for an interquartile change in pollutant } \\
\text { measure* }\end{array}$} \\
\hline & & Current hour & 24 hour MA \\
\hline \multirow[t]{3}{*}{$\mathrm{PM}_{2.5}$} & Effect $(95 \% \mathrm{Cl})$ & 1.36 (0.58 to 2.14$)$ & $1.45(0.33$ to 2.57$)$ \\
\hline & $\mathrm{N}$ & 253 & 282 \\
\hline & $p$ value & 0.0008 & 0.012 \\
\hline \multirow[t]{3}{*}{ NO } & Effect $(95 \% \mathrm{Cl})$ & 0.40 (0.01 to 0.79$)$ & $0.83(0.26$ to 1.40$)$ \\
\hline & $\mathrm{N}$ & 213 & 241 \\
\hline & $\mathrm{p}$ value & 0.047 & 0.0046 \\
\hline \multirow[t]{2}{*}{$\mathrm{NO}_{2}$} & $\begin{array}{l}\text { Effect }(95 \% \mathrm{Cl}) \\
\mathrm{N}\end{array}$ & $\begin{array}{l}0.00(-0.77 \text { to } 0.78) \\
138\end{array}$ & $\begin{array}{l}0.53(-0.35 \text { to } 1.41) \\
177\end{array}$ \\
\hline & $\mathrm{p}$ value & 0.99 & 0.24 \\
\hline \multirow[t]{2}{*}{$\mathrm{O}_{3}$} & $\begin{array}{l}\text { Effect }(95 \% \mathrm{Cl}) \\
\mathrm{N}\end{array}$ & $\begin{array}{l}-0.92(-1.93 \text { to } 0.08) \\
229\end{array}$ & $\begin{array}{l}-0.30(-1.36 \text { to } 0.75) \\
256\end{array}$ \\
\hline & p value & 0.074 & 0.57 \\
\hline \multirow{3}{*}{$\mathrm{SO}_{2}$} & Effect $(95 \% \mathrm{Cl})$ & $0.09(-0.22$ to 0.41$)$ & $0.24(-0.61$ to 1.10$)$ \\
\hline & & 243 & 278 \\
\hline & p value & 0.56 & 0.58 \\
\hline
\end{tabular}

$M A=$ moving average.

${ }^{*}$ Corrected for subject, week of study, day of week, hour of day, and 24 hour mean temperature, pressure, and relative humidity. Significant effects $(p<0.05)$ are shown in bold.

Table 4 Multi-pollutant models for $\mathrm{PM}_{2.5}$, ambient NO, and room NO

\begin{tabular}{|c|c|c|c|c|}
\hline \multirow[b]{2}{*}{ Pollutant } & \multicolumn{4}{|c|}{ Estimated change in $\mathrm{FE}_{\mathrm{NO}}(\mathrm{ppb}$ ) for an interquartile change in pollutant measure } \\
\hline & Model 1 & Model 2 & Model 3 & Model 4 \\
\hline \multicolumn{5}{|c|}{$\mathrm{PM}_{2.5}$ (24 hour) } \\
\hline Effect & 1.95 & 1.38 & - & \\
\hline $95 \% \mathrm{Cl}$ & (0.47 to 3.43 ) & $(0.26$ to 2.51$)$ & & (0.48 to 3.46$)$ \\
\hline$p$ value & 0.011 & 0.017 & & 0.011 \\
\hline \multicolumn{5}{|c|}{ Ambient NO (24 hour) } \\
\hline Effect & 0.54 & - & 0.73 & 0.43 \\
\hline $95 \% \mathrm{Cl}$ & $(-0.10$ to 1.18$)$ & & (0.12 to 1.34 ) & $(-0.25$ to 1.10$)$ \\
\hline$p$ value & 0.099 & & 0.02 & 0.215 \\
\hline \multicolumn{5}{|l|}{ Indoor NO } \\
\hline Effect & - & 0.69 & 0.26 & 0.30 \\
\hline $95 \% \mathrm{Cl}$ & & (0.04 to 1.34$)$ & $(-0.56$ to 1.08$)$ & $(-0.53$ to 1.13$)$ \\
\hline$p$ value & & 0.038 & 0.54 & 0.48 \\
\hline
\end{tabular}

*Each model includes pollutant variables for which estimates are reported, as well as the following covariates: subject ID, week of study, day of week, hour of day, and 24 hour mean temperature, pressure, and relative humidity. Significant effects $(p<0.05)$ are shown in bold. 
transport, our results suggest that ambient $\mathrm{PM}_{2.5}$ and $\mathrm{NO}$ are most consistently associated with exhaled NO levels. We also observed negative associations (non-significant) between current hour and 24 hour ozone exposures and exhaled NO. These results were probably due to the negative correlation between ambient NO concentrations and both ozone (Pearson correlation coefficient $r=-0.38$ for 24 hour ozone exposure) and fine particles $\left(r=-0.23\right.$ for 24 hour $\mathrm{PM}_{2.5}$ exposure). Two-pollutant models confirmed this, since the magnitude of the negative ozone effect was reduced in models with $\mathrm{PM}_{2.5}$ (models not shown). Ambient ozone concentrations are typically inversely correlated with NO concentrations in areas with local sources, since NO reacts rapidly with ozone.

In studies where NO is removed from inhaled air, it is important to consider NO levels in the breath sampling area as a possible contributor to measured levels in exhaled breath. ${ }^{25}$ While room NO levels in the study were significantly associated with exhaled NO in many of our multivariate models, this factor did not significantly alter the estimates of the main pollutant effects for ambient $\mathrm{NO}$ and $\mathrm{PM}_{2.5}$. In 24 hour exposure models, room NO levels were more likely to be significant than in short exposure models; this may be a function of the degree of correlation between current room NO concentrations and relatively contemporaneous moving averages of ambient pollution. For example, the Pearson correlation coefficients between $\mathrm{NO}$ in the study room and the current hour and the 24 hour moving average of $\mathrm{PM}_{2.5}$ were 0.55 and 0.27 , respectively.

The associations we have observed may represent subclinical changes that elucidate the biological mechanisms responsible for the established epidemiological link between exposure to air pollution and health. However, the absolute changes observed here may be considered small in clinical terms. For example, children with acute asthma have been shown to exhibit exhaled NO levels that are several times higher than those in comparable normal subjects $(31.3 \mathrm{v}$ $5.4 \mathrm{ppb}) .^{26}$ The differences between patients with stable asthma and normal subjects have been reported to be smaller (for example, $13.9 \vee 6.2 \mathrm{ppb}$ ), ${ }^{27}$ consistent with our observations (table 1). (It should be noted that published exhaled NO levels vary widely due to variations in collection techniques and populations under study.)

The observed association with $\mathrm{PM}_{2.5}$ is supported by studies that link the broader class of particles $\left(\mathrm{PM}_{10}\right)$ to pulmonary inflammation in animal models, ${ }^{3}$ as well as direct evidence that links $\mathrm{PM}_{10}$ exposure to induction of iNOS. ${ }^{28}$ Recent epidemiological studies have observed associations between ambient particle pollution and measures of systemic inflammation including white blood cell count, ${ }^{4} 29$ fibrinogen ${ }^{29}$ and $\mathrm{C}$ reactive protein. ${ }^{30}$ Other studies have found that ambient particle levels predict reduced heart rate variability ${ }^{5}$ and increased vascular tone ${ }^{7}$ which may, in part, be responses to either pulmonary or systemic inflammation. Exposures to specific components of particulate matter have also been shown to stimulate the release of inflammatory mediators including diesel exhaust particles. ${ }^{31}$ Acute oxidant exposure such as cigarette smoke inhalation has also been shown to release NO from epithelial lining fluid. ${ }^{32} 33$ These pathways may be partly responsible for the link between air pollution exposure and cardiovascular morbidity and mortality.

Ultimately, we would like to assess the role of specific components of the measured fine particle mass on our outcome. Air pollution in Steubenville has been dominated historically by industrial sources. For example, in a source apportionment study of fine particles and mortality, $\mathrm{PM}_{2.5}$ in Steubenville was predominantly associated with coal combustion during the period 1979-88. ${ }^{34}$ However, the relative role of exposure to fine particles from industrial or other specific sources such as traffic cannot be determined in this study because compositional data are not available.

The association we have observed between exhaled NO and ambient NO raises several important issues. This association has been reported in studies by Van Amsterdam et $a l^{21}$ and by Steerenberg et al,,$^{22}$ although these authors speculated that ambient $\mathrm{NO}$ and $\mathrm{CO}$ might be serving as a surrogate for a mixture of pollutants that includes the causative agent $(s)^{21}$ since gas phase NO has not been shown to increase endogenous NO production directly. These unmeasured pollutants may include the number concentration of fine particles or their composition. However, while numerous studies have linked $\mathrm{NO}_{2}$ exposure to pulmonary and cardiovascular morbidity, ${ }^{35}{ }^{36}$ compounds closely related to $\mathrm{NO}_{2}$ such as $\mathrm{NO}$, nitrous/nitric acid, or nitrates are rarely included in studies of air pollution epidemiology due to a presumption of no effect or because of the paucity of measurements. These compounds, like $\mathrm{PM}_{2.5}$, can be markers of motor vehicle emissions and thus might only partially identify the causative agent. While exposure to $\mathrm{NO}_{2}$ has been shown to contribute to pulmonary inflammation, these effects have generally been observed at concentrations much higher than those occurring in ambient air. ${ }^{37}$ However, the potential for exposure to oxides of nitrogen and related species to affect NO production as a biologically important end point has not been explored. Unfortunately, as shown in table 3, a significant number of $\mathrm{NO}_{2}$ measurements are missing in our data set, thus limiting our ability to fully explore these associations and co-pollutant effects. Overall, these associations need to be confirmed in experimental or observational settings.

Our results suggest that the effects of pollution on exhaled NO might not be immediate. These observations are consistent with the finding that markers of systemic inflammation generally do not increase immediately following the precipitating event and may remain raised for hours to days. ${ }^{38}$ Specifically, proinflammatory cytokines such as IL-6 and TNF- $\alpha$ control a cascade of events that can include the production of acute phase proteins as well as the induction of nitric oxide synthase. ${ }^{38}$ In a recent longitudinal study the authors showed that the association between exhaled NO and ambient pollution persisted for at least 5 hours. ${ }^{21}$

There are several limitations to our study. Disease status was determined by each subject's self-report of a doctor's diagnosis. There is therefore some uncertainty about the true disease state of our subjects, but previous studies have shown that reversibility studies are unable to distinguish between asthma and COPD in the elderly..$^{30}$ The absence of spirometric testing is also a limitation of the study, although it may not have enabled us to distinguish between asthma and COPD in our study population. We used continuous air monitors located at a central outdoor site in Steubenville to represent each subject's personal exposure, despite certain differences in the activity and personal environments of the study group. However, the study was conducted simultaneously with a comprehensive exposure assessment performed on a subset of 10 participants which showed that the median subject specific correlation coefficient between personal and central site ambient $\mathrm{PM}_{2.5}$ concentrations (24 hour measurements) was 0.76 (range $0.34-0.91 ; \mathrm{n}=197$ ). These results suggest that personal and ambient $\mathrm{PM}_{2.5}$ concentrations are highly associated for our study population and support our use of the central site data. While exhaled NO has been shown to be a marker of pulmonary inflammation, another limitation of our study is that the source of the exhaled NO we have measured is unknown. NO production pathways other than inflammation related enzymatic upregulation have been proposed. For example, previous studies have suggested that exhaled NO may originate from bioequivalent forms in the epithelial lining 
fluid such as S-nitrosothiols or peroxynitrite. The release of NO from these molecules may be a function of the local redox state..$^{20} 32$

Mechanistic studies of the health effects of air pollution have typically relied on the inhalation or instillation of concentrated particles in animal models. This study offers a means of exploring the mechanisms responsible for the health effects of real exposures to ambient pollution in humans using an easily applied, non-invasive, repeatable technique. Further research will be necessary, however, to determine the source of excess NO related to these exposures and whether this evidence supports a role for exhaled NO as a marker for associated changes in subclinical inflammation.

\section{ACKNOWLEDGEMENTS}

The authors thank Dr Tony Massaro and Jo-Ellen Brodeur for their invaluable guidance on the collection of breath samples, George Allen for his technical assistance with the NOx analyser, Sara Krilich and Kathleen Carey for their many hours of breath sample analysis in Steubenville, the numerous field staff from the Franciscan University of Steubenville for their overwhelming support in data collection efforts, Marina Canner for her thorough statistical review, Brent Coull for his statistical advice on the repeated measures ANOVA, and the study subjects in Steubenville for their enthusiastic participation and for welcoming us into their community.

\section{Authors' affiliations}

G Adamkiewicz, M Syring, F E Speizer, J Schwartz, D R Gold,

Channing Laboratory, Department of Medicine, Brigham and Women's Hospital and Harvard Medical School, Boston, MA 02115, USA

S Ebelt, F E Speizer, J Schwartz, H Suh, D R Gold, Exposure,

Epidemiology and Risk Program, Department of Environmental Health, Harvard School of Public Health, Boston, MA, USA

J Slater, Department of Chemistry, Franciscan University of Steubenville, Steubenville, OH, USA

This work was supported by funding from the National Institute of Environmental Health Sciences (grants ES-00002, ES09825), the US Environmental Protection Agency (grants R82-6780-010, R827353-01$0)$, and the National Heart Lung and Blood Institute (grant HL07427).

\section{REFERENCES}

1 Dockery DW. Epidemiologic evidence of cardiovascular effects of particulate air pollution. Environ Health Perspect 2001;109(Suppl 4):483-6.

2 American Thoracic Society. Health effects of outdoor air pollution. Committee of the Environmental and Occupational Health Assembly of the American Thoracic Society. Am J Respir Crit Care Med 1996;153:3-50.

3 Li XY, Gilmour PS, Donaldson K, et al. Free radical activity and proinflammatory effects of particulate air pollution (PM10) in vivo and in vitro. Thorax 1996:51:1216-22.

4 Salvi S, Blomberg A, Rudell B, et al. Acute inflammatory responses in the airways and peripheral blood after short-term exposure to diesel exhaust in healthy human volunteers. Am J Respir Crit Care Med 1999;159:702-9.

5 Gold DR, Litonjua A, Schwartz J, et al. Ambient pollution and heart rate variability. Circulation 2000;101:1267-73.

6 Pope CA 3rd, Verrier RL, Lovett EG, et al. eart rate variability associated with particulate air pollution. Am Heart J 1999;138(5 Pt 1):890-9.

7 Brook RD, Brook JR, Urch B, et al. Inhalation of fine particulate air pollution and ozone causes acute arterial vasoconstriction in healthy adults. Circulation 2002; 105: 1534-6.

8 Saetta M. Airway inflammation in chronic obstructive pulmonary disease. Am J Respir Crit Care Med 1999;160:S17-20.

9 Corrigan $\mathrm{CJ}, \mathrm{Kay} A \mathrm{~B}$. The roles of inflammatory cells in the pathogenesis of asthma and of chronic obstructive pulmonary disease. Am Rev Respir Dis 1991; 143:1165-88, discussion 1175-6.

10 Ridker PM, Hennekens CH, Buring JE, et al. C-reactive protein and other markers of inflammation in the prediction of cardiovascular disease in women. N Engl J Med 2000;342:836-43.
11 Zanzinger J. Role of nitric oxide in the neural control of cardiovascular function. Cardiovasc Res 1999;43:639-49.

12 DeGroote M, Fang F. NO inhibitions: antimicrobial properties of nitric oxide. Clin Infect Dis 1995;21(Suppl 2):S162-5.

13 Bogdan C. Nitric oxide and the immune response. Nat Immunol 2001;2:907-16.

14 Barnes PJ, Liew FY. Nitric oxide and asthmatic inflammation. Immunol Today 1995; 16:128-30.

15 Gaston B, Drazen JM, Loscalzo J, et al. The biology of nitrogen oxides in the airways. Am J Respir Crit Care Med 1994;149:538-51.

16 Chatkin JM, Ansarin K, Silkoff PE, et al. Exhaled nitric oxide as a noninvasive assessment of chronic cough. Am J Respir Crit Care Med 1999;159:1810-3.

17 Clini E, Bianchi L, Ambrosino N. Exhaled nitric oxide in COPD patients. Monaldi Arch Chest Dis 2001;56:169-70.

18 Kharitonov SA, Yates D, Springall DR, et al. Exhaled nitric oxide is increased in asthma. Chest 1995;107(3 Suppl):156-7S

19 Gwynn RC, Burnett RT, Thurston GD. A time-series analysis of acidic particulate matter and daily mortality and morbidity in the Buffalo, New York, region. Environ Health Perspect 2000;108:125-33.

20 Hunt JF, Fang K, Malik R, et al. Endogenous airway acidification. Implications for asthma pathophysiology. Am J Respir Crit Care Med 2000;161:694-9.

21 Van Amsterdam JG, Verlaan BP, Van Loveren H, et al. Air pollution is associated with increased level of exhaled nitric oxide in nonsmoking healthy subjects. Arch Environ Health 1999;54:331-5.

22 Steerenberg PA, Nierkens S, Fischer PH, et al. Traffic-related air pollution affects peak expiratory flow, exhaled nitric oxide, and inflammatory nasal markers. Arch Environ Health 2001;56:167-74

23 Silkoff PE. Recommendations for standardized procedures for the online and offline measurement of exhaled lower respiratory nitric oxide and nasal nitric oxide in adults and children-1999. Am J Respir Crit Care Med 1999; 160:2104-17.

24 Mattes J, van's Gravesande KS, Moeller C, et al. Circadian variation of exhaled nitric oxide and urinary eosinophil protein $\mathrm{X}$ in asthmatic and healthy children. Pediatr Res 2002;51:190-4.

25 Therminarias A, Flore P, Favre-Juvin A, et al. Air contamination with nitric oxide: effect on exhaled nitric oxide response. Am J Respir Crit Care Med 1998;157:791-5.

26 Baraldi E, Azzolin NM, Zanconato S, et al. Corticosteroids decrease exhaled nitric oxide in children with acute asthma. J Pediatr 1997;131:381-5.

27 Massaro AF, Gaston B, Kita D, et al. Expired nitric oxide levels during treatment of acute asthma. Am J Respir Crit Care Med 1995;152:800-3.

28 Martin LD, Krunkosky TM, Dye JA, et al. The role of reactive oxygen and nitrogen species in the response of airway epithelium to particulates. Environ Health Perspect 1997; 105(Suppl 5):1301-7.

29 Schwartz J. Air pollution and blood markers of cardiovascular risk. Environ Health Perspect 2001;109(Suppl 3):405-9.

30 Peters A, Frohlich M, Doring A, et al. Particulate air pollution is associated with an acute phase response in men; results from the MONICA-Augsburg Study. Eur Heart J 2001;22:1198-204.

31 Bayram H, Devalia JL, Sapsford RJ, et al. The effect of diesel exhaust particles on cell function and release of inflammatory mediators from human bronchial epithelial cells in vitro. Am J Respir Cell Mol Biol 1998;18:441-8.

32 Chambers D, Tunnicliffe W, Ayres J. Acute inhalation of cigarette smoke increases lower respiratory tract nitric oxide concentrations. Thorax 1998;53:677-9.

33 Balint B, Donnelly L, Hanazawa T, et al. Increased nitric oxide metabolites in exhaled breath condensate after exposure to tobacco. Thorax 2001;56:456-61

34 Laden F, Neas LM, Dockery DW, et al. Association of fine particulate matter from different sources with daily mortality in six U.S. cities. Environ Health Perspect 2000;108:941-7.

35 Peters JM, Avol E, Gauderman WJ, et al. A study of twelve Southern California communities with differing levels and types of air pollution. II. Effects on pulmonary function. Am J Respir Crit Care Med 1999;159:768-75.

36 Peters A, Liu E, Verrier RL, et al. Air pollution and incidence of cardiac arrhythmia. Epidemiology 2000;11:11-7.

37 Gilmour M, Park P, Selgrade M. Increased immune and inflammatory responses to dust mite antigen in rats exposed to $5 \mathrm{ppm} \mathrm{NO}_{2}$. Fundam Appl Toxicol 1996;31:65-70.

38 Gabay C, Kushner I. Acute-phase proteins and other systemic responses to inflammation. N Engl J Med 1999;340:448-54.

39 Lewis S, Weiss S, Britton J. Airway responsiveness and peak flow variability in the diagnosis of asthma for epidemiological studies. Eur Respir J $2001 ; 18: 921-7$.

40 Soriano J, Davis K, Coleman B, et al. The proportional Venn diagram of obstructive lung disease: two approximations from the United States and the United Kingdom. Chest 2003;124:474-81. 